\title{
Hubungan Tingkat Pengetahuan terhadap Perilaku Swamedikasi Common Cold di Apotek X Kabupaten Nganjuk
}

\author{
Nur Fahma Laili ${ }^{1 *}$, Anggi Restyana ${ }^{2}$, Neni Probosiwi $^{3}$, Lisa Savitri $^{4}$, Elly Megasari $^{5}$, \\ Tridoso Sapto A ${ }^{6}$, Evi Laela Sari ${ }^{7}$, La'ally Maula ${ }^{8}$ \\ 1,2,3,5,6,7,8,Program Studi Farmasi, Universitas Kadiri, Jalan Selomangleng no. 1 Kota Kediri \\ ${ }^{4}$ Program Studi Teknologi Laboratorium Medis, Universitas Kadiri, Jalan Selomangleng no. 1 Kota Kediri \\ *Correspondence email: nurfahmalaili@unik-kediri.ac.id
}

\begin{abstract}
Abstrak. Common cold atau disebut salesma merupakan infeksi saluran pernafasan atas yang disebabkan oleh virus. Pengobatan common cold dapat dilakukan dengan swamedikasi. Swamedikasi merupakan salah satu bentuk upaya masyarakat guna memelihara dan meningkatkan kesehatan. Swamedikasi membutuhkan pengetahuan yang baik untuk menghasilkan perilaku yang baik. Penelitian ini bertujuan untuk mengetahui hubungan pengetahuan terhadap perilaku swamedikasi common cold di apotek $\mathrm{x}$ Kabupaten Nganjuk. Penelitian merupakan penelitian observasional deskriptif dengan rancangan penelitian cross sectional dengan pengambilan data melalui kuisioner pengetahuan dan perilaku. Dari hasil penelitian didapatkan 104 responden penelitian yang memenuhi kriteria inklusi. Hasil penelitian yang didapatkan yaitu tingkat pengetahuan tinggi $(59,6 \%)$, sedang $(38,5 \%)$, rendah $(1,9 \%)$, untuk tingkat perilaku baik $(73,1 \%)$, sedang $(24,0 \%)$, kurang $(2,9 \%)$. Nilai signifikansi yang diperoleh sebesar 0,000 dan nilai koefisien korelasi dengan arah korelasi positif kuat sebesar 0,513 yang berarti terdapat hubungan antara tingkat pengetahuan terhadap perilaku swamedikasi common cold di apotek X kabupaten Nganjuk.
\end{abstract}

Kata Kunci: Common cold; pengetahuan; perilaku

Abstract. Common cold or salesmas is an upper respiratory tranct infection caused by a virus. Therapy of the common cold can be done through self-medication. Self-medication is a form of community effort to maintain and increase health level. Selfmedication requires good knowledge to result good behavior. This study aims to determine the corelation between knowledge on the behavior of self-medication of common cold in apotek $x$ Nganjuk regency. This research is a descriptive observational study with a cross sectional research design with data collection through knowledge and behavior questionnaires. From the research results obtained 104 research respondents who met the inclusion criteria. The results obtained are high level of knowledge (59.6\%), moderate (38.5\%), low (1.9\%), for the level of good behavior (73.1\%), moderate (24.0\%), less (2.9\%). The significance value obtained is 0.000 and and the value of the correlation coefficient with a strong positive correlation direction of 0.513 which means that there is a relationship between the level of knowledge on the behavior of self-medication of common cold in apotek $x$ in Nganjuk regency.

Keyword: common cold; knowledge; behavior

\section{PENDAHULUAN}

Setiap masyarakat wajib melakukan kegiatan upaya kesehatan guna untuk memelihara dan meningkatkan derajat kesehatan masyarakat dalam bentuk pencegahan penyakit, peningkatan kesehatan, pengobatan penyakit dan pemulihan kesehatan (Depkes, 2009). Swamedikasi merupakan salah satu bentuk upaya masyarakat untuk memelihara kesehatan diri dengan cara melakukan pengobatan sendiri tanpa resep dokter. Pengobatan swamedikasi digunakan untuk mengatasi gejala dan penyakit yang mampu didiagnosis oleh pasien sendiri. (WHO, 2000).

Hasil data survei sosial ekonomi nasional (Susenas) tahun 2014 menunjukkan bahwa persentase penduduk di Jawa Timur yang melakukan pengobatan sendiri selama sebulan terakhir menggunakan obat modern sebesar 89,42\% dan obat tradisional sebesar 24,74\%. Penelitian Zulkarni et al., (2019) menyebutkan bahwa sumber utama obat swamedikasi $75 \%$ berasal dari apotek $16 \%$ berasal dari toko obat/warung dengan alasan masyarakat menggunakan obat secara swamedikasi adalah saran dari anggota keluarga (28\%), pengalaman sebelumya $27 \%$.

Common cold biasa disebut dengan salesma merupakan suatu infeksi saluran pernafasan atas ringan yang disebabkan oleh virus yang sering terjadi dimasyarakat. Gejala common cold yang muncul pada masing-masing individu berbeda-beda tergantung pada daya tahan dan respons tubuhnya, sehingga common cold merupakan penyakit yang dapat sembuh dengan sendirinya (self limited) dengan durasi 7 -10 hari (Lee, 2018). Pengobatan pada common cold yaitu masuk dalam obat kategori bebas terbatas yang dijual bebas di apotek seperti dengan pemberian analgesik, dekongestan hidung dengan atau tanpa antihistamin, ecpectoran, antitusif (Katharine et al., 2019)

Pengetahuan seseorang terhadap kesehatannya akan menentukan cara seseorang berperilaku. Perilakunya terhadap penyakit dapat berupa perilaku seseorang berupaya mencari pengobatannya (health seeking behavior) dimana perilaku seseorang berupaya mengobati dirinya sendiri terhadap penyakitnya 
(swamedikasi). Swamedikasi menjadi pilihan penanggulangan pertama masyarakat untuk meredakan atau menyembuhkan keluhan kesehatan yang ringan sebelum pergi ke fasilitas kesehatan. Masyarakat melakukan swamedikasi karena dinilai hemat biaya, untuk sakit ringan, hemat waktu, bersifat sementara jika sakit berlanjut segera menghubungi dokter atau tenaga kesehatan. (Notoatmodjo, 2010; Aswad T A et al., 2019).

Penelitian ini bertujuan untuk mengetahui hubungan pengetahuan terhadap perilaku swamedikasi common cold di apotek x Kabupaten Nganjuk. Hasil penelitian dapat memberikan dorongan untuk masyarakat agar lebih aktif mencari informasi obat tentang common cold dan dapat digunakan menjadi masukan bagi apoteker dalam pelayanan kefarmasian khususnya swamedikasi di apotek x Kabupaten Nganjuk.

\section{METODE}

Penelitian ini merupakan penelitian observasinal deskriptif dengan menggunakan rancangan penelitian dengan desain cross sectional dengan pengambilan sampel dilakukan secara accidental sampling. Populasi dalam penelitian ini yaitu pasien yang membeli obat common cold di apotek x Kabupaten Nganjuk. Variabel bebas pada penelitian ini adalah pengetahuan tentang swamedikasi common cold sedangkan variabel terikat pada penelitian ini adalah perilaku swamedikasi common cold.

Kriteria inklusi pada penelitian ini adalah responden yang pernah melakukan swamedikasi common cold, responden yang datang ke apotek $\mathrm{x}$ Kabupaten Nganjuk untuk membeli obat common cold, bersedia mengisi kuisioner. Responden yang membeli obat common cold dengan menggunakan resep merupakan kriteria eksklusi. Waktu pengambilan data dilakukan pada bulan Januari - Februari 2021.

Sampel berjumlah 104 responden pembeli dan pengguna obat common cold yang sesuai dengan kriteria inklusi.

Data dikumpulkan menggunakan metode pengisian kuisioner pengetahuan dan perilaku swamedikasi pasien. Kuisioner pengetahuan terdiri dari 19 item pertanyaan dan kuisioner perilaku terdiri dari 10 item pertanyaan. Pada tiap pertanyaan diberi skor 1 untuk jawaban benar dan skor 0 untuk jawaban salah, dimana pada kuisioner ini menggunakan skala guttman. Kuisioner sebelum digunakan dalam penelitian dilakukan uji validitas dan uji reabilitas terlebih dahulu terhadap 45 responden dan telah dinyatakan valid dan reliable. Analisa data untuk menunjukkan adanya hubungan bermakna antara 2 variabel menggunakan uji korelasi Spearman rank dengan $\mathrm{P}$ value $<\alpha=0,05$.

\section{HASIL DAN PEMBAHASAN}

Sebanyak 104 responden yang terlibat pada penelitian ini berasal dari apotek x Kabupaten Nganjuk.
Berdasarkan hasil penelitian karakteristik responden pada Tabel 1, responden didominasi oleh perempuan (66\%) dengan kriteria usia 20-60 tahun (92\%) dengan sebagian besar responden tidak bekerja (52\%). Berdasarkan Penelitian Octavia et al (2019). Perempuan lebih peduli terhadap kesehatan jika dibandingkan lakilaki dan mayoritas responden yang berusia produktif membuat seseorang untuk mudah menggali informasi tentang obat. Mayoritas responden tidak bekerja atau sebagai ibu rumah tangga. Seorang ibu rumah tangga biasanya banyak mendapatkkan banyak pengetahuan dan lebih mudah bersosialisasi dengan di lingkungan tempat tinggalnya. Ibu rumah tangga sebagai pembuat keputusan dalam penggunaan obat di dalam keluarga.

Tabel 1. Karakteristik responden

\begin{tabular}{cccc}
\hline No & Data Umum & N (jumlah) & $\%$ \\
\hline \multirow{4}{*}{1} & Usia & & \\
2 & $17-19$ & 96 & 3 \\
3 & $20-60$ & 5 & 92 \\
& $>60$ & & 5 \\
\hline 1 & Jenis Kelamin & 35 & 34 \\
2 & Laki-laki & 69 & 66 \\
& Perempuan & & \\
\hline 1 & Pekerjaan & 50 & 48 \\
2 & Bekerja & 54 & 52 \\
\hline
\end{tabular}

Tabel 2. Tingkat pengetahuan swamedikasi common cold di apotek x Kabupaten Nganjuk

\begin{tabular}{llccl}
\hline \multirow{2}{*}{ No } & Indikator & \multicolumn{2}{c}{ Frekuensi } & Nomor sumber \\
\cline { 3 - 5 } & & Benar (\%) & Salah (\%) & Pertanyaan \\
\hline 1. & Mengetahui definisi common cold & 93 & 7 & 1 \\
2. & Mengetahui gejala common cold & 80 & 20 & $2,4,7$ \\
3. & Mengetahui penyebab common cold & 76 & 24 & $3,5,10$ \\
4. & $\begin{array}{l}\text { Mengetahui terapi farmakologi maupun } \\
\text { non farmakologi }\end{array}$ & 56 & 44 & $8,11,12,13$ \\
5 & $\begin{array}{l}\text { Mengetahui aturan minum obat } \\
\text { common cold }\end{array}$ & 83 & 17 & $6,9,16,17,18$ \\
6. & $\begin{array}{l}\text { Mengetahui efek samping obat } \\
\text { common cold }\end{array}$ & 95 & 5 & 14 \\
7. & Mengetahui stabilitas obat & 90 & 10 & 15,19 \\
\hline
\end{tabular}

Tabel 3. Kategori Tingkat pengetahuan swamedikasi common cold di apotek x Kabupaten Nganjuk

\begin{tabular}{lccc}
\hline No & Tingkat pengetahuan & Frekuensi (n) & Persentase (\%) \\
\hline 1 & Tinggi & 62 & 59,6 \\
2 & Sedang & 40 & 38,5 \\
3 & Rendah & 2 & 1,9 \\
& Jumlah & 104 & 100 \\
\hline
\end{tabular}

Tabel 4. Perilaku swamedikasi di apotek X Kabupaten Nganjuk

\begin{tabular}{llccl}
\hline No & \multicolumn{1}{c}{ Indikator } & \multicolumn{2}{c}{ Frekuensi } & Nomor sumber \\
& & Benar (\%) & Salah (\%) & Pertanyaan \\
\hline 1. & Tepat indikasi Obat & 83 & 17 & 1,3 \\
2. & Tepat aturan pakai & 81 & 19 & 4,6 \\
3. & Tepat lama pemberian & 85 & 15 & 2 \\
4. & Tepat cara penyimpanan & 84 & 16 & $5,7,9$ \\
5 & Tepat tindak lanjut & 79 & 21 & 8 \\
6 & Waspada efek samping & 67 & 33 & 10 \\
\hline
\end{tabular}


Tabel 5. Kategori tingkat perilaku swamedikasi common cold di apotek X Kabupaten Nganjuk

\begin{tabular}{lccc}
\hline No & Tingkat perilaku & Frekuensi (n) & Persentase (\%) \\
\hline 1 & Baik & 76 & 73,1 \\
2 & Cukup & 25 & 24,0 \\
3 & Kurang & 3 & 2,9 \\
\hline
\end{tabular}

\section{Tingkat pengetahuan swamedikasi di Apotek X kabupaten Nganjuk}

Analisis tingkat pengetahuan swamedikasi common cold menggunakan 7 kategori indikator, adapun 7 kategori indikator terdapat pada tabel 1. Pada tabel 1 terlihat frekuensi kesalahan terbesar yaitu pada indikator mengetahui terapi farmakologi dan non farmakologi (44\%). Pengobatan farmakologi yang digunakan pada common cold adalah dengan pemberian seperti dengan pemberian analgesik, dekongestan hidung dengan atau tanpa antihistamin (Katharine et al., 2019). Permasalahan terdapat dalam pemilihan obat yang kurang tepat yaitu responden menggunakan antibiotik untuk mengobati common cold tanpa mendapatkannya dari resep dokter. Penyakit common cold disebabkan oleh virus bukan bakteri sehingga dampak dari menggunaan antibiotik pada terapi common cold adalah meningkatnya resistensi bakteri dan timbul efek samping yang tidak diinginkan (Reese Richard E, et al. 2000). Sejalan dengan penelitian Pratiwi ageng et al., (2020) tentang pengetahuan penggunaan antibiotik secara swamedikasi menunjukkan bahwa pengetahuan yang kurang dapat menyebabkan penggunaan obat secara tidak tepat juga sehingga mayoritas responden memiliki cara penggunaan yang salah terhadap antibiotik (48\%) secara swamedikasi. Salah satu medication eror yang sering terjadi adalah penggunaan obat yang tidak sesuai dengan indikasinya, lebih dari $90 \%$ pasien dengan keluhan common cold mendapatkan antibiotika (Nugraha Dimas R \&Inayah., 2016).

Penyakit common cold dapat disembuhkan dengan terapi non farmakologi untuk mengatasi gejala awal dengan cara minum air putih, perbanyak istirahat, mengkonsumsi makanan hangat, berkumur dan minum air garam dan mengkonsumsi vitamin $\mathrm{C}$ (Fashner $\mathrm{J}$ et al., 2012). Pada penelitian ini (tabel 2) menunjukkan bahwa responden belum paham mengenai pengobatan common cold secara non farmakologi. Mengkonsumsi vitamin $\mathrm{C}$ dapat berfungsi sebagai antioksidan kuat dengan cara meningkatkan sistem kekebalan tubuh. Sistem kekebalan tubuh memiliki peran utama dalam melawan jenis infeksi virus dan menjaga kekebalan fungsi sel (Mehrtens J et al., 2017).

Berdasarkan data pada tabel 3 pengetahuan swamedikasi common cold di apotek $\mathrm{x}$ Kabupaten Nganjuk dikategorikan menjadi 3 yaitu pengetahuan tinggi $(76 \%-100 \%)$, pengetahuan sedang $(56 \%-75 \%)$, pengetahuan rendah $(<56 \%)$. Pada penelitian ini didapatkan bahwa tingkat pengetahuan swamedikasi common cold terbanyak pada responden di apotek $\mathrm{x}$
Kabupaten nganjuk yaitu 62 pasien $(59,6 \%)$ mempunyai pengetahuan tinggi, 40 responden $(38,5 \%)$ mempunyai pengetahuan sedang dan 2 responden $(1,9 \%)$ mempunyai pengetahuan rendah. Pada penelitian Jajuli $M$ \& Sinuraya., (2018) menjelaskan bahwa pengetahuan masyarakat dalam memilih pengobatan sendiri (swamedikasi) didapatkan dari pengalaman pengobatan sendiri, informasi dari keluarga dan atau teman, mendapatkan informasi dari media seperti ilan televisi maupun internet. Pengetahuan seseorang dapat dipengaruhi oleh faktor antara lain usia, tingkat pendidikan, jenis kelamin, tingkat pendapatan, banyaknya informasi, konsultasi dengan tenaga kesehatan dan sosial budaya masyarakat (Octavia et al., 2019).

\section{Tingkat perilaku swamedikasi di apotek $\mathrm{X}$ Kabupaten Nganjuk}

Pada tabel 4 perilaku mempuyai 6 indikator 4T $1 \mathrm{~W}$ antara lain tepat indikasi obat, tepat aturan pakai, tepat lama pemberian obat, tepat cara penyimpanan, tepat tindak lanjut waspada efek samping. Persentase kesalahan terbesar yaitu pada indikator waspada efek samping (33\%). Dari pertanyaan nomor 10 responden menjawab kurang tepat pada keadaan responden mengkonsumsi obat common cold pada saat kondisi berpergian. Pada pengobatan common cold diberikan terapi dengan pemberian analgesik, dekongestan hidung dengan atau tanpa antihistamin, expectoran, antitusif (Katharine et al., 2019). Kandungan anti histamine bekerja dengan mengurangi sekret hidung, wheezing, rhinitis. Analgesik digunakan untuk meringankan rasa sakit dan demanm. Decongestan mempunyai efek mengurangi hidung tersumbat. Ekspectoran digunakan untuk batuk berdahak, dan antitusif digunakan untuk batuk tidak berdahak. Pada umumnya efek samping yang muncul pada obat common cold adalah salah satunya mengantuk (Mark et al., 2017).

Berdasarkan tabel 5 data perilaku swamedikasi common cold di apotek x Kabupaten Nganjuk dibagi menjadi 3 kategori yaitu perilaku tinggi (76\%-100\%), perilaku sedang $(56 \%-75 \%)$, perilaku rendah $(<56 \%)$. Pada penelitian ini didapatkan bahwa tingkat perilaku swamedikasi common cold terbanyak pada responden di apotek X Kabupaten nganjuk yaitu 76 pasien $(73,1 \%)$ mempunyai perilaku baik, 25 responden $(24,0 \%)$ mempunyai perilaku cukup dan 3 responden $(2,9 \%)$ mempunyai perilaku kurang. Berdasarkan penelitian Efayanti Erina et al (2019) menyatakan bahwa terdapat hubungan antara motivasi dengan perilaku swamedikasi. Motivasi merupakan hasil yang ingin dicapai sesorang yaitu kesembuhan. Motivasi yang tinggi akan membuat seseorang berperilaku yang baik.

Pada penelitian ini data dianalisis menggunakan spss dengan pemilihan metode uji non parametrik yang digunakan adalah uji spearman rank untuk mengukur hubungan antara dua variabel (Sugiyono, 2019). Hasil 
taraf signifikansi yang diperoleh $0,000<0,05$ sehingga dapat dinyatakan $\mathrm{H} 1$ diterima , maka dapat dinyatakan bahwa variabel tingkat pengetahuan dan perilaku swamedikasi common cold secara signifikan berkorelasi atau berhubungan. Nilai koefisien korelasi yang diperoleh yaitu sebesar $(+0,513)$ dan masuk dalam kategori korelasi positif kuat, artinya hubungan yang terjadi antara tingkat pengetahuan dengan perilaku swamedikasi adalah kuat dan signifikan Hal ini menyatakan ada hubungan antara tingkat pengetahuan dengan perilaku swamedikasi common cold di apotek $\mathrm{x}$ kabupaten Nganjuk. Pengetahuan merupakan salah satu faktor yang dapat mempengaruhi terbentuknya tindakan seseorang. Perilaku yang didasari oleh pengetahuan akan lebih konsisten daripada perilaku yang tidak didasari pengetahuan (Notoatmodjo, 2010). Dengan demikian dapat disimpulkan semakin tinggi tingkat pengetahuan responden maka perilaku swamedikasi akan semakin baik, dan sebaliknya sebaliknya semakin rendah tingkat pengetahuan responden maka perilaku swamedikasi semakin kurang baik.

\section{SIMPULAN}

Terdapat hubungan antara tingkat pengetahuan terhadap perilaku swamedikasi common cold di apotek $\mathrm{X}$ kabupaten Nganjuk dengan taraf signifikansi sebesar 0,000 dan koefisien korelasi positif kuat sebesar 0,513.

\section{DAFTAR PUSTAKA}

Aswad Tri Anggraini, Kharisma Yuktiana, Andriane Yuke, Respati Titik , Nurhayati Eka (2019). Pengetahuan dan Perilaku Swamedikasi oleh IbuIbu di Kelurahan Tamansari Kota Bandung. Jurnal Integrasi Kesehatan \& Sains, 1(2):107113.

Departemen Kesehatan Republik Indonesia. 2009. Undang - Undang No. 39 Tahun 2009 tentang Kesehatan. Jakarta: Departemen Kesehatan RI; 2009.

Efayanti Erina, Susilowati Tri, Imamah Ida Nur, (2019). Hubungan Motivasi dengan perilaku swamedikasi. Jurnal Penelitian Perawat Profesional, Global Health Science Gruup: 1 (1): 21-32.

Fashner J, et al., (2012) Treatment of the common cold in adults and children. American Family Physician. 86:153.

Fashner Julia, Ericson Kevin, Werner Sarah (2012). Treatment of the common cold in children and adults, American Family Physician 15;86(2):1539.

Jajuli, M., dan Sinuraya, R.K., (2018). "Artikel Tinjauan: Faktor-Faktor yang Mempengaruhi dan Resiko Pengobatan Swamedikasi" Farmaka, 16 (1): 48-53.

Katharine C. Degeorge, Md, Ms; Daniel J. Ring, Md; And Sarah N. Dalrymple, Md, (2019) Treatment Of The Common Cold . University Of Virginia
Department Of Family Medicine, Charlottesville, Virginia, , American Family Physician. 1;100(5):281-289.

Lee, Hesol KMD, MSa; Kang, Bohyung KMD, BAa; Choi, Jun-Yong KMD, PhDb; Park, Sunju KMD, PhDc; Lee, Myeong Soo PhDd; Lee, Ju Ah KMD, $\mathrm{PhDa}$. (2018). Eunkyosan for treatment of the common cold A protocol for the systematic review of controlled trials. Medicine. 97:18.

Mark A. Malesker, PharmD, FCCP; Priscilla CallahanLyon, MD; Belinda Ireland, MD; Richard S. Irwin, MD; Master FCCP; on behalf of the CHEST Expert Cough Panel. (2017). Pharmacologic and Nonpharmacologic Treatment for Acute Cough Associated With the Common Cold, CHEST Expert Panel Report, CHEST 2017; 152(5):1021-1037

Mehrtens, J. et al., (2017). Hypovitaminosis C and vitamin C Deficiency in Critically Ill Patients Despite Recommended Enteral and Parenteral Intakes. Critical Care, 11 December, 21(300), pp. $1-10$

Notoatmodjo S. 2010. Ilmu Perilaku Kesehatan. Jakarta: PT Rineka Cipta.

Nugraha Dimas P, Inayah, (2016). Gambaran Farmakoterapi Pasien Common Cold Di Puskesmas Pekanbaru, JIK, 10:1 Hal. 63-66

Octavia Devi Ristian, Zakaria Muhammad Syahrizal , Nurafifah Dian, (2019). Tingkat Pengetahuan Masyarakat Tentang Swamedikasi yang Rasional di Lamongan, Jurnal surya, 11:3

Pratiwi Ageng I, Weny I. Wiyono, Imam Jayanto1, (2020) Pengetahuan Dan Penggunaan Antibiotik Secara Swamedikasi Pada Masyarakat Kota, Jurnal Biomedik. 12(3):176-185.

Reese Richard E, et al., (2000). Handbook of Antibiotics.3rd ed. Lippincott Williams\&Wilkins, Philadelphia 2000: 3-5

R, Z., Tobat, S. R., \& Aulia, S. F. (2019). Perilaku Masyarakat Dalam Swamedikasi Obat tradisional Dan Modern di Kelurahan Sapiran Kecamatan Aur Birugo Tigo Baleh kota bukittinggi. Jurnal Kesehatan, 10(1), 1. doi:10.35730/jk.v10i1.382

Sugiyono (2019). Statistika untuk Penelitian. Bandung : CV Alfabeta.

WHO (2000) Guidelines for the Regulatory Assessment of Medicinal Products for Use in SelfMedication., Geneva. Terdapat pada: http://apps.who.int/medicinedocs/pdf/s2218e/s221 8e.pdf. Diakses: 28 Agustus 2021. 